\title{
O SIGNIFICADO DA EXPRESSÃO “UTILIZAR TRIBUTO COM EFEITO DE CONFISCO” NA DOUTRINA E NA JURISPRUDÊNCIA DA CORTE CONSTITUCIONAL BRASILEIRA: APROXIMAÇÃO OU DISTANCIAMENTO DO SEU SENTIDO COMUM?
}

\author{
Iris Cintra Basilio*1
}

\begin{abstract}
Resumo: Este trabalho se propõe a explorar o sentido da vedação à instituição de tributo confiscatório. Inicialmente busca o sentido comum da linguagem adotada pelo constituinte. Posteriormente, sua definição doutrinária. Finalmente, a significação construída pelo julgador constitucional. Ao fim de cada tópico, reescreve o texto constitucional com palavras semelhantes em significado, porém impregnadas dos elementos acrescentados pelo senso comum, pela ciência jurídica e pelo órgão jurisdicional. O tema se apresenta relevante, ao esclarecer se o sentido do texto constitucional se assemelha àquele que lhe atribui a doutrina pátria e o STF.
\end{abstract}

Palavras-chave: Teoria da linguagem; Direito Tributário; vedação ao confisco; definição.

\section{THE MEANING OF THE EXPRESSION "USING TAX WITH CONFISCATORY EFFECT" IN THE DOCTRINE AND IN THE JURISPRUDENCE OF THE BRAZILIAN CONSTITUTIONAL COURT: APPROXIMATION OR DISTANCE OF ITS COMMON SENSE?}

\begin{abstract}
This paper proposes to explore the meaning of prohibition to the institution of confiscatory tribute. Initially it seeks the common sense of the language adopted by the constituent. Subsequently, its doctrinal definition. Finally, the meaning built by the constitutional judge. At the end of each topic, it rewrites the constitutional text with words similar in meaning but impregnated with elements added by common sense, legal science and the court. The theme is relevant when clarifying whether the meaning of the constitutional text resembles that attributed to it by the doctrine and the Supreme Court.
\end{abstract}

Keywords: Theory of language; tax law; prohibition to confiscation; definition.

\footnotetext{
1 * Advogada. Mestranda em Direito Público pela Universidade Federal de Alagoas (UFAL). MBA em Direito Tributário pela Fundação Getúlio Vargas (FGV). Conselheira da Associação dos Tributaristas de Alagoas (ATRIAL). Professora Universitária. Endereço profissional: Av. Menino Marcelo, n. 9350, Edf. Empresarial Humberto Lôbo, Sala 1518, Serraria, Maceió, Alagoas, CEP n. 57.046-005. E-mail: iris@cintrabasilio.com.br.
} 


\section{INTRODUÇÃO}

A Constituição da República de 1988 veda a instituição de tributo com efeito de confisco (art. 150, IV), mensagem direcionada, num primeiro momento, ao legislador infraconstitucional. Não há, contudo, uma conceituação na lei do que seja “confisco tributário” ou do que produza efeito semelhante. Ao se instituir a proibição, não houve indicação de sentido diverso do uso comum das palavras ali postas.

Este trabalho se propõe a buscar tal sentido, explorando a acepção de modo a chegar ao que poderia ser considerado uso comum da linguagem adotada pelo constituinte. Analisa as definições legais (como aquela disposta no Código Tributário Nacional (CTN), art. $3^{\circ}$, no que se refere ao conceito de tributo), verifica o que seria “confisco”, em que consistiria o ato de “instituir” exação com efeito confiscatório e se as punições (como as multas) estariam protegidas pela disposição constitucional. Ao final do primeiro tópico, constrói uma significação habitual do enunciado, ou seja, aquela utilizada no uso comum da linguagem pela comunidade jurídica.

A vedação direciona-se "num primeiro momento”, como se disse acima, ao legislador infraconstitucional. Em momento posterior, doutrina e jurisprudência construirão sentido semelhante ou diverso daquele constitucionalmente estabelecido. Por esse motivo, no segundo tópico, se analisará o conceito da expressão indicada na doutrina. Ao se debruçar sobre as inúmeras definições constantes de obras gerais ou específicas sobre o tema, o presente trabalho construirá um segundo sentido para a expressão “confisco tributário” reunindo os pontos de convergência a respeito do assunto.

O tópico seguinte dá ênfase à significação construída pelo julgador. Para tanto, explora acórdãos do Supremo Tribunal Federal (STF) proferidos desde a década de 50 e tenta identificar, do conjunto de julgados analisados, o que a Corte Constitucional brasileira inseriu, ao longo da história, no conceito de vedação constitucional à instituição de tributo com efeito confiscatório. Este artigo elaborará uma terceira definição que reflete o atual posicionamento da jurisprudência a respeito do assunto, de modo que se possa, no tópico final, realizar um comparativo entre as significações comum, doutrinária e jurisprudencial.

Realizado tal cotejo, se esclarecerá se houve um distanciamento ou uma aproximação entre a significação dada pela doutrina e pela jurisprudência, de um lado, e o sentido comum e habitual da expressão constitucional, de outro. Será analisado se tal distanciamento ou aproximação revela conceito mais amplo ou mais restrito e, consequentemente, se se apresenta mais ou menos protetivo, sob a ótica do contribuinte, titular do direito fundamental de não ser 
tributado em excesso. O presente trabalho indicará qual dos sentidos deve prevalecer e se algumas das significações encontradas se encontram fora das interpretações possíveis, se é que o julgador está adstrito ao espaço interior de alguma “moldura”.

O tema se apresenta relevante, na medida em que, ao pretender decifrar a mensagem transmitida pelo legislador, esclarece se o conceito que vem à lume nas mentes daqueles que realizam uma leitura inicial e apressada do texto constitucional se assemelha àquele que lhe atribui a doutrina pátria e o STF, tribunal que possui legitimidade para aplicar as normas extraídas do texto constitucional. Sua importância também se revela por auxiliar o processo de conhecimento da norma destinada ao sujeito cuja conduta se pretende influir.

\section{O SENTIDO COMUM DA EXPRESSÃO LINGUÍSTICA “UTILIZAR TRIBUTO COM EFEITO DE CONFISCO” PREVISTA NO ART. 150, INCISO IV, DA CR/1988}

Para afastar as dúvidas e incertezas que pairam sobre o enunciado constitucional, é importante descobrir o sentido da expressão linguística escolhida pelo legislador, especialmente para identificar se tais palavras têm o significado que normalmente costumam ter na linguagem em questão, ou seja, se são usadas do mesmo modo com que são utilizadas habitualmente pela comunidade jurídica (ALCHOURRON; BULYGIN, 1991, v. 24, p. 445). Quando o legislador quer utilizar sentido diverso (do uso comum) ele deve indicar expressamente (ALCHOURRON; BULYGIN, 1991, v. 24, p. 447), não sendo esse o caso ora em estudo. Trata-se da busca por uma definição informativa (MENDONCA, 1997, v. 4, p. 41) ou meramente descritiva.

Somente buscando o sentido das normas e revelando-o ao seu destinatário, o objetivo maior do direito poderá ser atingido, qual seja, a orientação das condutas humanas, relacionadas entre si, de modo a proporcionar a realização de valores relevantes à sociedade, dando-se, assim, eficácia à norma jurídica (CARVALHO, 2009a, p. 162). O que se encontra sob análise é, pois, o objeto do discurso comunicativo (“aquilo que se fala”) (FERRAZ JR., 2005, p. 30) ou, em outras palavras, a mensagem do emissor, direcionada ao receptor, por meio de uma conexão psicológica em determinado contexto (CARVALHO, 2009a, p. 166).

A descoberta do sentido da norma exige recurso ao uso comum da linguagem, de modo que se possa identificar qual é a definição habitual, utilizada pela comunidade jurídica, da expressão "utilizar tributo com efeito de confisco" que consta no art. 150, inciso IV, da Constituição da República de 1988. Tal análise se enquadra em um dos três planos 
fundamentais da linguagem, qual seja, o semântico (CARVALHO, 2009a, p. 199-200), o que se realiza mediante uma interpretação predominantemente literal e lógica do dispositivo em questão (CARVALHO, 2009a, p. 201).

Assim dispõe o referido artigo: “Art. 150. Sem prejuízo de outras garantias asseguradas ao contribuinte, é vedado à União, aos Estados, ao Distrito Federal e aos Municípios” [...] “IV - utilizar tributo com efeito de confisco”. Mas de que confisco será que o legislador constitucional está a tratar? Que condutas dos entes políticos podem provocar efeito de confisco no patrimônio do contribuinte? Somente a instituição de tributo pode provocar efeito de confisco? O que dizer da sua majoração? E as multas tributárias: podem estas vir a ser confiscatórias?

Inicialmente, observa-se que o constituinte escolheu o modal deôntico "proibido", restando nítida a desaprovação da sociedade quanto à conduta descrita no texto dispositivo mencionado (CARVALHO, 2009a, p. 175), qual seja, a de instituir tributos com efeitos confiscatórios. O emissor é o constituinte e a mensagem é direcionada inicialmente ao legislador infraconstitucional (CARVALHO, 2009a, p. 166) que, no momento da instituição de tributos deverá atentar para a vedação ali expressa.

O conceito de tributo consta no art. $3^{\circ}$, do Código Tributário Nacional: “Art. $3^{\circ}$. Tributo é toda prestação pecuniária compulsória, em moeda ou cujo valor nela se possa exprimir, que não constitua sanção por ato ilícito, instituída em lei e cobrada mediante atividade administrativa plenamente vinculada." Trata-se de um dos poucos conceitos, expressos legislativamente, acolhidos “de modo incondicional e entusiástico” pela comunidade jurídica (CARVALHO, 2009b, p. 102-103)³. A palavra tributo, pois, abrange todas as espécies consideradas tributárias ${ }^{4}$ e exclui as sanções por ato ilícito, dentre as quais, as multas. Instituir tributo é criá-lo, editar ato legal (eis que somente por lei, via de regra, se pode instituí-lo ${ }^{5}$ ) tendente a fazer surgir nova prestação pecuniária compulsória a ser suportada por determinado grupo de contribuintes. "Em sua principal significação, pois, instituição quer exprimir a criação ou a constituição de alguma coisa, que se personaliza, segundo plano ou bases preestabelecidas,

\footnotetext{
${ }^{2}$ Para Ferraz Jr. (2005), a expressão “proibir” é uma das fórmulas digitais pelas quais a autoridade controla reações possíveis do endereçado do discurso normativo/comunicativo.

${ }^{3}$ Carvalho (2009b) não deixa de tecer críticas científicas ao conceito legal de tributo.

${ }^{4}$ Quando da promulgação da Constituição de 1988 houve controvérsias a respeito das espécies tributárias, tendo prevalecido a teoria que considera tributos os impostos, as taxas, as contribuições de melhoria, empréstimo compulsório e as contribuições especiais, num total de cinco espécies, portanto.

${ }^{5}$ Constituição da República de 1988, art. 150, inciso I: “Art. 150. Sem prejuízo de outras garantias asseguradas ao contribuinte, é vedado à União, aos Estados, ao Distrito Federal e aos Municípios: I - exigir ou aumentar tributo sem lei que o estabeleça; [...]."
} 
isto é, sob a imposição de regras, que passam a regê-las, enquanto existente” (SILVA, 1999, p. 438).

Quanto ao confisco, cujo efeito é vedado pelo dispositivo constitucional ora analisado, não há na legislação conceito expresso indicativo de seu sentido. Sendo assim, recorrendo aos lexicógrafos pode-se chegar a um conceito de confisco relacionado à perda da propriedade em decorrência de ato ilícito: “confisco ou confiscação, vocábulo derivado do latim confiscatio, de confiscare - em sentido restrito, é o ato pelo qual são apreendidos, ou adjudicados ao fisco, bens pertencentes a outrem, mediante a atuação administrativa ou decisão judicial, fundados em lei” (FRANÇA, 1977, vol. 17, p. 517).

Confisco indica, pois, uma punição. “Quer isto dizer que sua imposição, ou decretação, decorre da evidência de crimes ou contravenções praticados por uma pessoa, em virtude do que, além de outras sanções, impõe a lei a perda de todos ou de parte dos bens em seu poder, em proveito do erário público” (SILVA, 1999, p. 199).

A disposição constitucional veda a instituição de tributo com efeito de confisco. Quer isto dizer que não somente o confisco é proibido, mas qualquer ato que venha a produzir o mesmo efeito, que provoque, portanto, resultado semelhante. Exemplificativamente, o Imposto sobre Propriedade Territorial Urbana - IPTU não pode ter alíquota tão elevada que inviabilize a propriedade imóvel, impeça a manutenção do bem, sendo preferível aliená-lo, por acarretar custo tributário altíssimo e insuportável ao contribuinte.

Apesar da atividade definitória do legislador oferecer um marco de maior precisão terminológica $^{6}$, de maneira que residem menos variáveis as interpretações de um mesmo enunciado e mais seguras as expectativas dos destinatários em função da aplicação da norma contida em tal enunciado (MENDONCA, 1997, v. 4, p. 40), verifica-se que no caso do “confisco tributário” tal definição não consta na lei, o que dá margem a diferentes interpretações e acaba por deixar a tarefa a cargo do Poder Judiciário. A despeito da ausência de definição legal, se buscará construir um sentido mais ou menos determinado da referida expressão utilizado habitualmente pela comunidade jurídica (MENDONCA, 1997, v. 4, p. 39).

Da leitura da expressão constante do art. 150, inciso IV, da CR/1988, após análise das palavras que a compõe, da disposição destas no texto e do sentido de cada uma delas individualmente verificadas, pode-se, à vista do que se expôs, extrair o seguinte significado

\footnotetext{
${ }^{6}$ Mendonca (1977, v. 4) ensina que somente o uso estipulativo das definições (aquele que cria nova significação para determinado termo) se justifica em contextos legais. Seria desnecessário e redundante utilizar significações de uso comum, pois o direito se expressa na linguagem natural da comunidade.
} 
comum: no exercício do poder de tributar é proibido ao legislador infraconstitucional criar prestações pecuniárias compulsórias que, de tão excessivas, provoquem efeitos equivalentes à perda da propriedade dos contribuintes sobre os bens que lhes pertencem, não se aplicando tal restrição à instituição de punições decorrentes da prática de ato ilícito.

À luz do ordenamento em vigor, estas seriam as palavras parcialmente equivalentes em significado à expressão analisada (MENDONCA, 1997, v. 4, p. 40-41), algo como uma frase conceitual reescrita pelas expressões definidas sem alterar o significado da oração em que ela aparece $^{7}$.

\section{CONSTRUÇÃO DOUTRINÁRIA DO CONCEITO DA VEDAÇÃO AO CONFISCO TRIBUTÁRIO}

A interpretação doutrinária, realizada pela ciência jurídica, para Kelsen, não cria Direito, não é autêntica, tratando-se de "pura determinação cognoscitiva do sentido das normas jurídicas” (KELSEN, 1999, p. 250). De todo modo, sua verificação se apresenta relevante, pois a ciência jurídica contribui, com o resultado de suas pesquisas, para a construção de argumentos que serão utilizados pelos tribunais quando do julgamento de casos concretos, o que facilita a análise destes, razão pela qual este tópico antecede aquele relativo à apreciação da jurisprudência.

Neste momento os planos semântico e pragmático da linguagem ganham destaque (CARVALHO, 2009a, p. 199-200), pois os conceitos doutrinários apresentados tomam como base o resultado da análise prévia dos termos jurídicos que constam do enunciado constitucional acrescidos de uma conotação histórica e teleológica do direito (CARVALHO, 2009a, p. 201), levando em consideração, em sua construção, o sentido jurisprudencial da acepção que será visto no tópico subsequente. É algo cíclico. Doutrina e jurisprudência se influenciam mutuamente, numa cadeia de argumentos utilizados ou descartados na análise dos casos concretos.

A não-confiscatoriedade, não confisco ou vedação ao confisco tributário, considerado por alguns um princípio (ÁVILA, 2005, p. 70), por outros uma regra dotada de elevado cunho axiológico (CARVALHO, 2009a, p. 257), em definição doutrinária singela, representa a proibição de “absorção total ou substancial da propriedade privada, pelo Poder Público, sem a correspondente indenização” (COSTA, 2012, p. 83-84). A proibição deriva do princípio da

\footnotetext{
${ }^{7}$ Seria o mesmo que afirmar, como o faz Mendonca: “vedação ao confisco tributário” se define como --- (1997, v. 4, p. 41).
} 
capacidade contributiva, tendo em vista que "as leis que criam impostos, ao levarem em conta a capacidade econômica dos contribuintes, não podem compeli-los a colaborar com os gastos públicos além de suas possibilidades” (CARRAZZA, 2004, p. 89). É, portanto, confiscatório “o imposto que, por assim dizer, “esgota” a riqueza tributável das pessoas” (CARRAZZA, 2004, p. 89).

A impossibilidade de instituição de tributo excessivo decorre também da previsão contida no CTN, art. $3^{\circ}$, que conceitua tributo como prestação pecuniária compulsória "que não constitua sanção de ato ilícito”. Lógica se apresenta, pois, a conclusão de que não pode ser ele utilizado com efeito confiscatório.

Contudo, a dicção constitucional expressa não impede a prática de abusos pelos entes tributantes. A comodidade do Poder Público, as necessidades de caixa do Tesouro Nacional e a assunção de novas (e cada vez mais complexas) tarefas pelo Estado são razões que levam à constante tentativa de aumento da arrecadação via tributação excessiva. As práticas são variadas e se concretizam "por meio da edição de novas leis, que instituam novos tributos ou que elevem os já existentes” (ÁVILA, 2016, p. 72), “mediante a prolação de novas decisões judiciais, que afastem eventuais inconstitucionalidades das leis tributárias ou que mantenham os seus efeitos pretéritos” (ÁVILA, 2016, p. 72), mesmo quando sejam frontalmente contrárias aos ditames constitucionais.

Tais motivos não podem ser usados como justificativa para permitir a violação dos direitos subjetivos dos contribuintes, assegurados constitucionalmente. "Um desses direitos é exatamente o de só ser tributado pela pessoa política competente e da forma pontuada pela Lei Magna” (CARRAZZA, 2004, p. 382-383).

É consenso na doutrina que a referida proteção se destina às pessoas físicas e jurídicas, ou seja, aos contribuintes em geral. Ressalta Roque Antonio Carrazza que "para as empresas, o confisco está presente, quando o tributo, de tão gravoso, dificulta-lhes sobremodo a exploração de suas atividades econômicas habituais” (2004, p. 89). É que, nas relações dessa natureza, “reserva-se um papel especial para a pessoa jurídica que, na maior parte das situações concretas, é quem figura no polo passivo de obrigações tributárias” (LIMA NETO, 2005, p. 134).

Para boa parte da doutrina o princípio do não confisco tributário (e dos demais princípios constitucionais que limitam o poder de tributar) se insere na categoria de direito fundamental do contribuinte (CARRAZZA, 2004, p. 378-379; BALEEIRO; DERZI, 2013, p. 102; ÁVILA, 
2016, p. 246; LIMA NETO, 2005, p. 127), o que lhe confere os atributos de autoaplicabilidade, prevalência, integridade, irreversibilidade e inesgotabilidade (ÁVILA, 2016, p. 246).

E quanto às sanções decorrentes da prática de ato ilícito (as multas, por exemplo)? A vedação as atingiria? Humberto Ávila responde ao questionamento, ao alertar: “entender que a regra de proibição de instituição de tributo com efeito confiscatório, prevista no inciso IV do art. 150 da CR/88, tem seu âmbito de proteção limitado ao que dispõe a sua hipótese diminuiria as garantias do contribuinte em vez de aumentá-las” (2016, p. 435). Para o autor, “a eficácia direta e a aplicação proporcional dos princípios da proteção da liberdade e da propriedade afastariam não apenas a instituição de tributos com efeito de confisco, mas também a cobrança de obrigações acessórias e de multas excessivas” (2016, p. 435).

Paulo de Barros Carvalho manifesta entendimento semelhante, pois para ele a cobrança da multa em percentual excessivo "consubstancia um verdadeiro confisco, figura que a Constituição brasileira também procura impedir” (2009a, p. 880). A doutrina, de modo geral, defende a proibição de se impor sanção confiscatória ao contribuinte (BALEEIRO; DERZI, 2013, p. 1.272-1.273; LIMA NETO, 2005, p. 236), bem como a aplicação da proporcionalidade e/ou da razoabilidade na aferição do caráter confiscatório das multas (CARVALHO, 2009a, p. 881).

Da leitura dos diversos posicionamentos doutrinários acima expostos a respeito da expressão constante do art. 150, inciso IV, da CR/1988, pode-se extrair o seguinte significado: no exercício do poder de tributar é proibido ao legislador infraconstitucional criar prestações pecuniárias compulsórias e sanções por descumprimento de obrigação principal ou acessória, alterar as já existentes ou fixar-lhes novos critérios, de modo que sejam ou se tornem tão excessivas, a ponto de provocar efeitos equivalentes à perda da propriedade dos contribuintes sobre os bens que lhes pertencem, sejam pessoas físicas (quando não poderá o legislador adentrar em áreas reservadas aos direitos à vida, à liberdade, à igualdade, à segurança e à propriedade), sejam pessoas jurídicas (quando ao legislador será vedado dificultar-lhes sobremodo a exploração de suas atividades econômicas habituais), não havendo um limite objetivo que estejam compelidos a obedecer, mas devendo ser pautados pela proporcionalidade elou razoabilidade das medidas impostas.

Trata-se de conceito da ciência do direito que reúne os principais pontos de esclarecimento do sentido da vedação constitucionalmente prevista. 


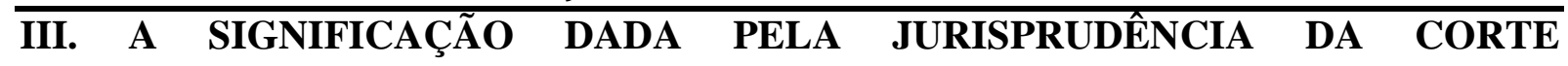
CONSTITUCIONAL BRASILEIRA

Alchourron e Bulygin (1991, p. 452) entendem que os juízes só estão obrigados a usar as definições legais quando estas tenham sido efetivamente usadas pelo próprio legislador; só então seu uso seria condição necessária para a identificação da norma. Não havendo definição legal da expressão “confisco tributário” no sistema jurídico brasileiro, poder-se-ia afirmar que os magistrados estão “livres” para criar definições para esse conceito? O que estaria, nesse caso, dentro da moldura interpretativa das normas jurídicas?

Kelsen (1999, p. 246) entende que há duas espécies de interpretação das normas jurídicas: aquela que lhe dá o órgão que a aplica ("autêntica”) e a outra, dada por uma pessoa privada e pela ciência jurídica (“não autêntica”). A primeira intepretação, que denomina “autêntica” é realizada pelo órgão julgador com uma margem maior ou menor de livre apreciação, pois a norma nunca vincula totalmente o ato por meio do qual é aplicada. Dessa forma, “a norma do escalão superior tem sempre, em relação ao ato de produção normativa ou de execução que a aplica, o caráter de um quadro ou moldura a preencher por este ato" (KELSEN, 1999, p. 246).

Mas como o intérprete saberá quais possibilidades de aplicação se encontram dentro da moldura? Para o autor, o simples fato de decidir, levado a efeito pelo Tribunal quando aplica a norma a um caso concreto, se mostra como a identificação da moldura de que se está a tratar, pois o julgador é quem determina a "normas individuais que podem ser produzidas dentro da moldura da norma geral” (KELSEN, 1999, p. 247). Todas as interpretações realizadas pelo órgão julgador estariam, portanto, corretas, não sendo uma preferível à outra, por ser ele um “criador do Direito” e por ser sua interpretação sempre “autêntica” (KELSEN, 1999, p. 249), devendo ser enquadrada sempre dentro da moldura, ainda que possa parecer completamente fora dela.

Se o juiz cria o Direito por meio da interpretação autêntica, dando significado às expressões linguísticas, é possível crer que de tais signos, ou seja, do sentido das palavras previstas no texto legal, se pode extrair a norma jurídica motivadora da conduta social que se pretende ver seguida (MENDONCA, 1997, v. 4, p. 39). Havendo discrepância entre o sentido comum da expressão e aquele construído posteriormente, é correto afirmar que a norma constitucional sob análise restou adaptada às novas circunstâncias da vida. Mesmo sem alteração no texto da lei, pode-se considerar que a norma foi alterada. Se os juízes atribuem 
outro sentido às mesmas palavras, está-se na presença de outra norma (ALCHOURRON; BULYGIN, 1991, v. 24, p. 446; KELSEN, 1999, p. 249).

A definição dada pelo aplicador do direito baseia-se, em parte, no significado supostamente atribuído pelo legislador, sendo, pois, aclaratória (MENDONCA, 1997, v. 4, p. 42). Visa eliminar incertezas reais ou potenciais que determinado termo apresenta. O que se pretende com a análise realizada neste tópico é, pois, a partir das normas individuais e concretas criadas pelos órgãos credenciados pelo sistema jurídico por meio da incidência em casos particulares (CARVALHO, 2009a, p. 169), extrair o significado da norma constitucional, de modo a contribuir para o esclarecimento do sentido do texto ali posto e, consequentemente, com a eficácia desse mesmo sistema.

Aqui se dará atenção ao plano pragmático da linguagem, por meio do estudo do direito aplicado a casos concretos, que sofre influência dos critérios sistemático, histórico e teleológico de interpretação da norma, em muitos dos acórdãos proferidos (CARVALHO, 2009a, p. 200201). A verdade é, pois, criada pelo homem (alguém dotado de certa autoridade, como o julgador constitucional), dentro de determinado sistema, com base na força retórica da linguagem (MOUSSALLEM, 2001, p. 38). É esta verdade construída que se pretende esclarecer.

O STF tem se posicionado sobre o tema da vedação ao confisco tributário desde a década de 50, mesmo sob a égide da Constituição anterior, ou seja, não se trata de assunto limitado ao texto constante do art. 150, IV, da CR/1988. Inúmeros casos de contribuintes alegando abuso na tributação (e na fixação de multas), chegaram à Corte Constitucional e têm sido por ela solucionados.

Quanto à possível confiscatoriedade decorrente da fixação de tributos, podem ser citados, exemplificativamente, julgados a respeito dos seguintes assuntos: a) Imposto de Licença sobre Cabines de Banho ${ }^{8}$; b) Contribuição de Seguridade Social de Servidores Inativos ${ }^{9}$; c) ICMS $^{10}$.

\footnotetext{
${ }^{8}$ BRASIL. Supremo Tribunal Federal. Recurso Extraordinário n. 18.976-SP. Relator Min. Barros Monteiro. ADJ 2 out. 1952.

9 BRASIL. Supremo Tribunal Federal. Ação Declaratória de Inconstitucionalidade n. 2010-MC. Relator Min. Celso de Mello. Tribunal Pleno. Jul. 30 set. 1999.

${ }^{10}$ BRASIL. Supremo Tribunal Federal. Ação Declaratória de Inconstitucionalidade n. 4628/DF. Relator Min. Luiz Fux. Tribunal Pleno. Jul. 17 set. 2014.
} 
APROXIMAÇÃO OU DISTANCIAMENTO DO SEU SENTIDO COMUM?

Neste primeiro julgado (RE n. 18.976-SP) o STF analisou o caso em que o Município de Santos (SP) majorou em aproximadamente 600\% (seiscentos por cento) o então denominado “imposto de licença sobre cabines de banho”. Diante da insurgência dos contribuintes locais, o Tribunal afirmou que "todo imposto que torne praticamente proibitiva a exploração de um comércio lícito deve ser considerado inconstitucional." ${ }^{11}$ Naquele caso específico, o STF concluiu não ter havido confiscatoriedade, pois a causa de não obtenção de lucro por parte dos comerciantes foi a má gestão de seus administradores e não a cobrança tributária em si.

No segundo julgado (ADI n. 2010-MC) o STF verificou que a alíquota da contribuição instituída, quando somada ao IRPF incidente sobre a mesma base (provento dos servidores) chegaria ao patamar de $47 \%$ (quarenta e sete por cento), montante que o Tribunal entendeu ser confiscatório. Para a Corte, o confisco restaria configurado quando o efeito cumulativo decorrente de múltiplas incidências tributárias criadas pela mesma entidade afetar de maneira substancial e irrazoável o patrimônio e/ou os rendimentos do contribuinte, comprometer o exercício do direito a uma existência digna, a prática de atividade profissional lícita ou a regular satisfação das necessidades vitais do contribuinte. Entendeu o Tribunal que a atividade estatal se acha condicionada ao princípio da razoabilidade e que, se não houver diretriz objetiva e genérica, deve ser usado o princípio da proporcionalidade.

No terceiro julgado (ADI n. 4628/DF), relativo ao regime instituído pelo Protocolo n. 21/2011 do ICMS, restou discutida naqueles autos a nova sistemática de tributação criada. Para o STF, o princípio do não confisco, que encerra direito fundamental do contribuinte, restou violado em seu núcleo essencial em face da nova sistemática, que legitimou a aplicação de alíquota interna do ICMS na unidade federada de origem e que exige novo percentual (diferencial de alíquota) na unidade destinatária final quando o adquirente não for contribuinte do referido tributo. Nas razões de julgamento constou informação de que estaria havendo apreensão de mercadorias por parte dos Estados, quando inadimplido o tributo objeto da controvérsia. Para o Tribunal, a retenção equivaleria ao confisco. De acordo com o voto, não seria o novo regime, mas a apreensão ilegal de mercadorias que violaria o princípio constitucional invocado.

Inúmeros casos de sanções alegadamente confiscatórias também foram analisados pelo STF. Desde a década de 60 aquele Tribunal manifesta entendimento no sentido de que há

\footnotetext{
${ }^{11}$ BRASIL. Supremo Tribunal Federal. Recurso Extraordinário n. 18.976-SP. Relator Min. Barros Monteiro. ADJ
} 2.10.1952. 
proibição constitucional de excesso aplicável às multas, não somente aos tributos, e que é possível graduá-las ou excluí-las. ${ }^{12}$ A controvérsia também se referiu ao limite da multa a ser aplicada em relação aos tipos de penalidade existentes. O STF manifestou entendimento no sentido de que $30 \%$ (trinta por cento) ${ }^{13}$ e $20 \%$ (vinte por cento) ${ }^{14}$ do valor do tributo seriam limites adequados para as multas moratórias devidas em virtude de mero inadimplemento injustificado, prevalecendo, na maioria dos julgados, o segundo patamar indicado. No que se refere às multas punitivas, há entendimento no sentido de que $100 \%$ (cem por cento) ${ }^{15}$ do valor do tributo seria o limite apropriado.

Os critérios utilizados pela Corte variaram. Os primeiros acórdãos se fundamentaram no fato da multa ter se tornado gravosa e exorbitante ${ }^{16}$ ou por se apresentar manifestamente abusiva, o que configurou ilegalidade do fisco ${ }^{17}$, justificando sua redução. Nesse último caso houve menção do relator à restrição prevista no Código Civil de 1916 (CC/1916), que limitava as cláusulas penais ao valor da obrigação principal (art. 920). O CTN também foi invocado (art. 108, IV), por admitir a equidade.

Outra fundamentação utilizada pelo Tribunal foi a da possibilidade do Poder Judiciário reduzir a multa fiscal quando os fatos tiverem ocorrido num período em que o Fisco era mais tolerante, quando não se tiver provado prejuízo ao Tesouro, tiver restado indefinido o dolo do

12 BRASIL. Supremo Tribunal Federal. RE 55906/SP. Relator Min. Luiz Gallotti. Segunda Turma. Jul. 27 maio 1969. BRASIL. Supremo Tribunal Federal. RE 61160/SP. Relator Min. Evandro Lins. Segunda Turma. Jul. 19 mar. 1968. BRASIL. Supremo Tribunal Federal. RE 78291/SP. Relator Min. Aliomar Baleeiro. Primeira Turma. Jul. 4 jun. 1974. BRASIL. Supremo Tribunal Federal. RE 81550/MG. Relator Min. Xavier de Albuquerque. Segunda Turma. Jul. 20 maio 1975. BRASIL. Supremo Tribunal Federal. RE 82510/SP. Relator Min. Leitão de Abreu. Segunda Turma. Jul. 11 maio 1976.Supremo Tribunal Federal. RE 91707/MG. Relator Min. Moreira Alves. Segunda Turma. Jul. 11 dez. 1979.

13 BRASIL. Supremo Tribunal Federal. RE 81550/MG. Relator Min. Xavier de Albuquerque. Segunda Turma. Jul. 20 maio 1975.

14 BRASIL. Supremo Tribunal Federal. RE 239964/RS. Relatora Min. Ellen Gracie. Primeira Turma. Jul. 15 abr. 2003. BRASIL. Supremo Tribunal Federal. RE 596429-AgR/RS. Relator Min. Joaquim Barbosa. Segunda Turma. Jul. 25 set. 2012.

15 BRASIL. Supremo Tribunal Federal. ADI 551/RJ. Relator Min. Ilmar Galvão. Tribunal Pleno. Jul. 24 out. 2002.

${ }^{16}$ BRASIL. Supremo Tribunal Federal. RE 55906/SP. Relator Min. Luiz Gallotti. Segunda Turma. Jul. 27 maio 1969.

17 BRASIL. Supremo Tribunal Federal. RE 78291/SP. Relator Min. Aliomar Baleeiro. Primeira Turma. Jul. 4 jun. 1974. 
contribuinte $^{18}$ ou quando a multa tiver assumido, pelo seu montante desproporcional, feição confiscatória $^{19}$. As multas seriam acessórias e não poderiam, como tal, ultrapassar o valor do principal. ${ }^{20}$ Adotou o Tribunal, neste caso, o critério da razoabilidade na análise do efeito confiscatório da multa instituída. Os julgados acima mencionados são citados como precedentes nos acórdãos mais recentes.

A leitura dos acórdãos acima selecionados denota a significação construída pelo julgador a respeito da expressão constante do art. 150, inciso IV, da CR/1988, que pode ser assim reescrita: no exercício do poder de tributar é proibido ao legislador infraconstitucional criar prestações pecuniárias compulsórias, sanções por descumprimento de obrigação principal ou acessória ou medidas de fiscalização, alterar as já existentes ou fixar-lhes novos critérios ou sistemáticas de funcionamento, de modo que sejam ou se tornem tão excessivas, a ponto de provocar efeitos equivalentes à perda da propriedade dos contribuintes sobre os bens que lhes pertencem. A proteção se destina tanto às pessoas físicas, não podendo o legislador afetar de maneira substancial e irrazoável o patrimônio elou os rendimentos do contribuinte, comprometer o exercício do direito a uma existência digna, à prática de atividade profissional lícita ou à regular satisfação das suas necessidades vitais; quanto às pessoas jurídicas, sendo vedado àquele tornar praticamente proibitiva a exploração de um comércio lícito. Deve o legislador atentar para eventual efeito cumulativo decorrente de múltiplas incidências tributárias criadas pela mesma entidade, não havendo um limite objetivo que estejam compelidos a obedecer no que se refere aos tributos, oportunidade em que deverão adotar a razoabilidade e, se não houver diretriz objetiva e genérica, deve ser usado o princípio da proporcionalidade. Quanto à instituição de sanções, não poderá fazê-lo de modo abusivo, devendo observar o patamar de 20\% (vinte por cento) para as multas moratórias e 100\% (cem por cento) para as multas punitivas, sendo consideradas confiscatórias as punições monetárias que excederem tais limites.

A fixação de limites objetivos pelo Poder Judiciário, no silêncio da lei, não está livre de críticas, mas tal análise ultrapassa as fronteiras do presente estudo. O importante a consignar é

18 BRASIL. Supremo Tribunal Federal. RE 82510/SP. Relator Min. Leitão de Abreu. Segunda Turma. Jul. 11 maio 1976.

19 BRASIL. Supremo Tribunal Federal. RE 91707/MG. Relator Min. Moreira Alves. Segunda Turma. Jul. 11 dez. 1979.

20 BRASIL. Supremo Tribunal Federal. ADI 551/RJ. Relator Min. Ilmar Galvão. Tribunal Pleno. Jul. 24 out. 2002. 
que há várias décadas a Corte Constitucional brasileira tem dado, de modo bastante amplo, aplicabilidade à proibição de confisco tributário.

\section{CONCEITO ATUAL DA EXPRESSÃO: APROXIMAÇÃO OU DISTANCIAMENTO DO SEU SENTIDO COMUM?}

O sentido comum da vedação à "instituição de tributo com efeito de confisco", demonstrado no primeiro tópico deste estudo, é infinitamente mais restrito do que aquele que lhe dá a doutrina e a jurisprudência. A significação habitual da expressão trata apenas da criação de tributo, limitado ao conceito previsto no art. $3^{\circ}$, do CTN. A definição doutrinária o amplia para incluir a majoração de obrigação principal (pagar tributo), a fixação ou alteração de obrigações acessórias, bem como a proibição de instituição de multas confiscatórias.

O julgador, por sua vez, além de acolher o conceito doutrinário nos acórdãos proferidos pela Corte Constitucional, vai mais além, estabelecendo que o efeito cumulativo decorrente de múltiplas incidências oriundas do mesmo ente tributante poderá acarretar inconstitucionalidade da exação, especifica critérios (proporcionalidade e razoabilidade) para sua mensuração e fixa limites objetivos (em percentual) à instituição de multas devidas em decorrência de atraso no pagamento de tributos ou por sonegação. Parece visíveis a "clausura sintática” e a "abertura semântico-pragmática do sistema do direito positivo” (MOUSSALLEM, 2001, p. 20).

No caso ora analisado, restaram identificados os três aspectos distintos e conexos do fenômeno normativo descrito por Daniel Mendonca (1997, p. 39), a saber: a) o ato normativo: disposição constitucional prevista no art. 150, IV, da CR/1988, executada pelo legislador constituinte originário em Brasília (DF), no dia 5 de outubro de 1988; b) o enunciado normativo: “sem prejuízo de outras garantias asseguradas ao contribuinte, é vedado à União, aos Estados, ao Distrito Federal e aos Municípios” [...] "IV - utilizar tributo com efeito de confisco”; e c) a norma: no exercício do poder de tributar é proibido ao legislador infraconstitucional criar prestações pecuniárias compulsórias, sanções por descumprimento de obrigação principal ou acessória ou medidas de fiscalização, alterar as já existentes ou fixar-lhes novos critérios ou sistemáticas de funcionamento, de modo que sejam ou se tornem tão excessivas, a ponto de provocar efeitos equivalentes à perda da propriedade dos contribuintes sobre os bens que lhes pertencem. A proteção se destina tanto às pessoas físicas, não podendo o legislador afetar de maneira substancial e irrazoável o patrimônio e/ou os rendimentos do contribuinte, comprometer o exercício do direito a uma existência digna, à prática de atividade profissional lícita ou à regular satisfação das suas necessidades vitais); quanto às pessoas jurídicas, sendo 
vedado àquele tornar praticamente proibitiva a exploração de um comércio lícito. Deve o legislador atentar para eventual efeito cumulativo decorrente de múltiplas incidências tributárias criadas pela mesma entidade, não havendo um limite objetivo que estejam compelidos a obedecer no que se refere aos tributos, oportunidade em que deverão adotar a razoabilidade e, se não houver diretriz objetiva e genérica, deve ser usado o princípio da proporcionalidade. Quanto à instituição de sanções, deve observar o patamar de 20\% (vinte por cento) para as multas moratórias e 100\% (cem por cento) para as multas punitivas, sendo consideradas confiscatórias as punições monetárias que excederem tais limites.

Cada um dos componentes do fenômeno normativo, acima descritos (ato, enunciado e norma), especifica e diferencia o status linguístico a que correspondem: pragmático, no caso do ato; sintático, no caso do enunciado; e semântico, no caso da norma (MENDONCA, 1997, v. 4, p. 39). Como se pode verificar, o enunciado difere da norma jurídica e somente estas últimas podem ser consideradas “expressões completas de significação deôntico-jurídica”( CARVALHO, 2009a, p. 183).

A norma revelada no presente estudo é aquela construída pelo julgador, ou seja, o conceito reescrito de “vedação ao confisco tributário” (alínea “c” acima), tendo em vista que a doutrina não cria direito (KELSEN, 1999, p. 250), cabendo ao órgão jurisdicional o preenchimento da moldura interpretativa. É esse o conteúdo que se encontra atualmente dentro do quadro, dando-lhe formato e cor.

\section{Conclusão}

A comparação realizada entre as definições comum, doutrinária e jurisprudencial revela que o sentido construído pelo órgão julgador se apresenta infinitamente mais amplo do que os dois anteriores. A análise da jurisprudência do STF demonstra, ainda, que o conceito doutrinário tem sido, em grande parte (senão em sua totalidade) aproveitado pelos julgadores quando da solução dos casos concretos postos sob seu crivo.

Há, pois, um distanciamento entre o sentido literal do texto constitucional, utilizado na linguagem habitual da comunidade jurídica, e aquele que lhe é atribuído no julgamento de casos concretos. Tal distanciamento não se apresenta de todo ruim sob a ótica do contribuinte, daquele que sofrerá o ônus da imposição excessiva ou da sanção confiscatória. É que o STF, ao ampliar o sentido da "vedação à instituição de tributo com efeito de confisco", nele inserindo a majoração ou qualquer outro tipo de alteração da obrigação principal ou acessória, bem como 
colocando as multas (moratórias e punitivas) sob o manto da proteção constitucional, dá maior eficácia ao limitado texto previsto no art. 150, IV, da CR/1988.

Quando se compreende que a vedação ao efeito confiscatório (e das demais normas constitucionais que limitam o poder de tributar) se insere na categoria de direito fundamental do contribuinte, com algumas características relevantíssimas, como autoaplicabilidade, prevalência, inesgotabilidade, dentre outras, como assegura parte da doutrina e restou asseverado pela Corte Constitucional em várias oportunidades, a consequência necessária será aquela no sentido de que tal direito fundamental conferido ao contribuinte merece obter do Poder Judiciário posicionamento que proporcione sua máxima eficácia. E assim tem acontecido.

\section{Referências}

ALCHOURRON, Carlos E.; BULYGIN, Eugenio. Analysis lógico y Derecho. Vol. 24. Madri: Centro de Estudios Constitucionales, 1991.

ÁVILA, Humberto. Teoria da Segurança Jurídica. 4ª ed. São Paulo: Malheiros, 2016.

Teoria dos princípios: da definição à aplicação dos princípios jurídicos. $4^{\mathrm{a}}$ ed. São Paulo: Malheiros, 2005.

BALEEIRO, Aliomar; DERZI, Mizabel Abreu Machado (atual.). Direito Tributário Brasileiro. 12 ${ }^{\mathrm{a}}$ ed. Rio de Janeiro: Forense, 2013.

CARraZZA, Roque Antonio. Curso de Direito Constitucional Tributário. 19a ed. São Paulo: Malheiros, 2004.

CARVALHO, Paulo de Barros. Direito Tributário, linguagem e método. $3^{\mathrm{a}}$ ed. São Paulo: Noeses, 2009a.

Teoria da norma tributária. 5ª ed. São Paulo: Quartier Latin, 2009b.

COSTA, Regina Helena. Princípio da capacidade contributiva. $4^{\mathrm{a}}$ ed. São Paulo: Malheiros, 2012.

FERRAZ JR., Tércio Sampaio. Teoria da norma jurídica. 4 ed. Rio de Janeiro: Forense, 2005. FRANÇA, R. Limongi (Coord.). Enciclopédia Saraiva do Direito. Vol. 17. São Paulo: Saraiva, 1977. 
KELSEN, Hans. Teoria pura do direito. Trad. João Baptista Machado. São Paulo: Martins Fontes, 1999.

LIMA NETO, Manoel Cavalcante de. Direitos fundamentais do contribuinte: limitações constitucionais ao poder de tributar. Recife: Nossa Livraria, 2005.

MENDONCA, Daniel. Interpretación y aplicación del derecho. Vol. 4. Almería: Servicio de Publicaciones Almería, 1997.

MOUSSALLEM, Tárek Moysés. Fontes do direito tributário. São Paulo: Max Limonad, 2001.

SILVA, De Plácido e. Vocabulário Jurídico. 16ª ed. Rio de Janeiro: Forense, 1999. 